\title{
COMENTÁRIO A
}

"DEMÔNIOS DA BRASILIDADE: NOTAS PARA UM NIILISMO TROPICAL” - SOBRE AUTORITARISMOS, FUNDAMENTALISMOS E OUTROS DEMÔNIOS: O POTENCIAL DA PSICOLOGIA ANALÍTICA COMO CHAVE DE LEITURA PARA O GOVERNO BOLSONARO

\author{
João Paulo S. Vilas Boas ${ }^{1}$
}

Referência do artigo comentado: GEWEHR, R. B. Demônios da brasilidade: notas para um niilismo tropical. Trans/Form/Açáo: revista de filosofia da Unesp, v. 44, n. 3, p. 343-370, 2021.

Em "Demônios da brasilidade: notas para um niilismo tropical", Rodrigo Barros Gewehr oferece um convite tâo pertinente quanto oportuno para refletir sobre "[...] as categorizações já inventadas para compreender a brasilidade (GEWEHR, p. 344)" - tais como o trabalho servil (Caio Prado Júnior), a cordialidade (S. Buarque de Holanda) e o autoritarismo (G. Freyre) - tomando como chave de leitura as reflexôes de C. G. Jung sobre o papel das forças psíquicas do inconsciente coletivo como deflagradoras e sustentadoras de fenômenos de natureza social, o que implica considerar tais traços característicos do ethos brasileiro como um conjunto de "[...] potenciais pulsionais que mobilizam estratos mais recônditos da psique (GEWEHR,

${ }^{1}$ Professor do curso de Licenciatura em Filosofia da Universidade Federal do ABC (UFABC) e do Mestrado Profissional em Filosofia (PROF-FILO), núcleos UFT e UFABC, São Bernardo do Campo, SP - Brasil. (D) https://orcid.org/0000-0003-3236-2674 E-mail: vilas.boas@ufabc.edu.br

https://doi.org/10.1590/0101-3173.2021.v44n3.28.p371

\section{(i)}


2021, P. 357)", os quais, inevitavelmente, acabam se manifestando na vida concreta.

Em vista da presente explosão de autoritarismos, fascismos e fundamentalismos, na sociedade brasileira, a possibilidade apresentada pelo autor - de pensar sobre esse tipo de ocorrência em termos de uma "epidemia psíquica (GEWEHR, 2021)" deflagrada pela ação inconsciente de "precipitados culturais (GEWEHR, 2021)" gestados, acumulados e fortalecidos ao longo de nossa história - mostra-se como uma valiosa hipótese hermenêutica para a compreensão desses fenômenos. Tẫo valiosa quanto o surpreendente prognóstico formulado por Jung, na década de 1930, acerca da futura guerra que viria a ser encampada pela Alemanha nazista, num ensaio sobre a figura mitológica de Wotan.

Partindo do princípio de que "[t]oda ação coletiva, arraigada no transcorrer do tempo histórico de um povo, produz traços, produz inércia como qualquer corpo (GEWEHR, 2021, P. 359)”, e ainda, que tal inércia "[...] dá conta de certa inspiração coletiva, de automatismos que se instalam no corpo da cultura (GEWEHR, 2021, p. 360)", é seguro afirmar que a consideraçáo da força do legado psíquico inconsciente, gestado ao longo de séculos de escravidão e realimentado pelas duas ditaduras do século $\mathrm{XX}$, é um complemento indispensável às tentativas de se explicar a gigantesca receptividade recentemente conquistada por discursos autoritários, belicosos e antidemocráticos, no Brasil, bem como pelos respectivos atores políticos que os personificam, as quais, até então, caracterizam-se pela descrição e análise dos fatos a partir de categorias econômicas, midiáticas, políticas, histórias e/ ou sociológicas.

A comparação bastante perspicaz do autor entre, de um lado, a magnitude do estardalhaço provocado pelo romance Macunaíma e, de outro lado, a intensidade da ressonância do protagonista do romance com processos psíquicos compartilhados pelos brasileiros, oferece-nos um panorama inédito para entendermos a ascensão da família Bolsonaro à cúpula do poder político, ladeada por figuras diretamente associadas a um perigoso radicalismo religioso, o qual se contrapóe abertamente não apenas a conhecimentos científicos consolidados, como também aos direitos humanos e aos princípios constitucionais de liberdade religiosa, igualdade de direitos e da laicidade do Estado. 
Até o presente, as tentativas de explicar a eleição de Bolsonaro e o fortalecimento de discursos autoritários, fundamentalistas e de extrema direita no Brasil, recorreram à associação entre, de um lado, a recessão econômica e o aumento do desemprego, no Brasil, após 2014, acompanhados de perto pela transformação do ex-presidente Lula e de seu partido em verdadeiros bodes expiatórios, aos quais foi imputada a culpa por todas as mazelas que atingiram o país, no referido período, e ainda, de outro lado, um amplo processo de manipulação eleitoral, levado a cabo principalmente através da disseminação deliberada de fake news nas redes sociais, ao longo de 2018, a qual foi grandemente intensificada durante os meses de campanha eleitoral.

Conquanto tais reflexôes de matriz econômica, histórica, política e/ou sociológica tenham importância absolutamente incontestável, elas são incapazes de dar conta do elemento demoníaco perceptível no atual governo. Referimonos aqui à popularidade inaudita que certos discursos flagrantemente falsos e absurdos, para não dizer irracionais, vêm conquistando, tanto entre membros da cúpula do governo como entre as fileiras de apoiadores do atual presidente da República - as quais, sem dúvida, incluem indivíduos das classes média e alta que tiveram acesso a uma educação de qualidade - , tais como: as crenças de que Terra seria plana e de que o nazismo seria uma ideologia de esquerda; a classificação dos médicos cubanos enviados para trabalhar no programa Mais Médicos como agentes secretos da ditadura comunista; a condenação unilateral das universidades públicas e do conhecimento produzido no país, entre outros.

A transformação de várias dentre essas crenças desarrazoadas em princípios norteadores das políticas públicas, assim como a obstinação inquebrantável e aparentemente imune ao aprendizado com a qual seus adeptos se engajam em defendê-las dentro e fora das redes sociais, são ocorrências que simultaneamente confirmam o caráter incompleto das análises econômicas, sociológicas e políticas do Brasil atual, ao mesmo tempo que apontam para a magnitude da força dos já referidos "potenciais pulsionais", capazes de arrebatar e mover a todos nós, "[...] apesar da disposição crítica que nutrimos, ou supomos nutrir.” (GEWEHR, 2021, p. 346).

Soma-se a isso o caráter inequivocamente pessoal e visceralmente agressivo com o qual as divergências políticas vêm sendo tratadas. Os extremismos da polarização ideológica e a pessoalização dos ataques têm contribuído para transformar os espaços - tanto físicos como virtuais-de debate democrático sobre políticas públicas, teorias econômicas, direitos humanos 
etc. em verdadeiras arenas, onde a violência discursiva direta, juntamente com sortilégios argumentativos de toda espécie, são disseminados com o objetivo de suplantar a racionalidade de quaisquer argumentos contrários e soterrar o debatedor, que é encarado como um inimigo a ser combatido e derrotado. A degeneração do agonismo e do debate impessoal, racional e desapaixonado, numa franca troca de agressóes, torna perceptível o quanto de demoníaco reside na cordialidade dos brasileiros.

O fato de tais debates obstinados e radicalmente polarizados serem naturalmente desgastantes e infrutíferos revela insustentável a continuidade deles, o que, por sua vez, contribui igualmente para o esvaziamento das discussões democráticas, acompanhado pela intensificação do segregacionismo e do isolamento entre as diversas facçóes rivais. Tendo em vista que todos os fundamentalismos só florescem em meio ao isolamento, é seguro concluir que o enfraquecimento do caráter agonístico desses espaços de debate público só tende a fortalecer os fundamentalismos e corroer ainda mais a nossa já frágil democracia.

A ameaça representada por esse prognóstico nada animador evidencia o quão urgente e necessária é a tarefa de abrir novas veredas reflexivas sobre o Brasil e a brasilidade. A complexidade das dinâmicas sociais, políticas, culturais, religiosas, históricas, econômicas e também pulsionais, as quais, juntas, integram o contexto do presente, não comporta reducionismos nem soluções simplistas. Pelo contrário, para aqueles que se dispóem a levar a cabo a difícil tarefa de pensar criticamente sobre o país, é necessário coragem e disposição para não ignorar o demoníaco, nos indivíduos e nas massas. Nesse mister, o arcabouço teórico da psicologia analítica é, sem dúvida, um aliado precioso.

\section{REFERÊNCIA}

GEWEHR, R. B. Demônios da brasilidade: notas para um niilismo tropical. Trans/ Form/Açáo: revista de filosofia da Unesp, v. 44, n. 3, p. 343-370, 2021.

Recebido: 26/11/2020

Aceito: 03/12/2020 